\title{
Bionics in engineering education considerations, experiences and conclusions
}

\author{
Ralf Neurohr* and Cristian Dragomirescu \\ Politehnica University of Bucharest, Splaiul Independentei 313, Bucharest, 060032, Romania
}

(Received 26 February 2008; final version received 28 May 2008)

\begin{abstract}
During recent years bionics, a new discipline which is in charge with the transfer of the principles of construction, regulation, interaction and organisation of biology into innovative technical solutions, has attracted significant interest from various industries. Based on this request for bionic expertise in engineering, the faculty for teaching engineering in foreign languages (FILS) at 'Politehnica' University of Bucharest started a course in bionics in SS 2007, which was supported by the expertise of the German 'Bionik-Kompetenz-Netz', one of the leading organizations in bionics. This is the report on the considerations involved in the course concept, the first experiences with the students' acceptance, some conclusions and future perspectives for extending bionics activities at 'Politehnica'. Finally, within the last section, the evaluation of a questionnaire, filled in by the students at the end of the course, will be presented. In order to avoid any confusion, considering overlapping or mixing up with other bio-disciplines related to technology, the paper starts with a short introduction, explaining the principles of bionics and providing a clear definition of the field.
\end{abstract}

Keywords: bionics; teaching concepts; course evaluation

\section{Introduction}

Bionics, as an emerging field at the interface of biology and the world of classical engineering, is gaining more and more acknowledgement and interest from various branches of industry and economy. The already wide spread, but still increasing application of bionic concepts and strategies in product and process development, will lead to an higher request for engineers with a solid background knowledge in this field, accompanied by consistent practical experience in the application of the tools and ideas offered by bionics. Based on these considerations, 'Politehnica' University of Bucharest, the oldest and one of the leading technical universities in Romania, started in the summer semester 2007 the course 'Introduction into Bionics for Engineers' offered to the students of the German stream within the Department for teaching engineering in foreign languages (FILS). The further development of these activities will be based on an open cooperation with the German 'Bionik-KompetenzNetzwerk (BIOKON), which was founded in 2001 in order to promote this new field of research and gather the forces of the major national players.

In order to understand the general approach of bionics and its benefit for modern engineering, but also to avoid some misunderstandings and confusions due to interferences with terms like biotechnology or bioengineering, a short introduction into the fundamentals and principles of bionics, as well as its definition, will be presented first.

\section{What is bionics?}

Although the historical roots of bionics can be traced back to the time of Leonardo da Vinci, the Italian medieval age genius, or maybe even to earlier times, the definition of bionics as a modern research discipline was given less than 15 years ago by Neumann (1993) and may be translated as: 'Bionics is the scientific discipline of the systematic transfer of construction, process and evolution principles from living systems into technical applications'. In extension of this definition, Neumann also emphasises the importance of including aspects of the interaction between bio-systems or between bio-systems and their environment, which can be applied to economic and management systems as well. Nachtigall (2003), one of the pioneers in German bionics, gave a short abstract of this formal definition with the sentence 'Bionics is learning from nature for the creation of independent technical solutions', which is underlining the important fact that the major goal is not copying of nature. Bionics is not searching for master templates that can be directly transferred into a technical solution, as it is done by biomimetics, which sometimes by mistake is used as a synonym for bionics. Biomimetics, the special branch where copying nature lead to useful and innovative technical solutions, has to be regarded only as one part of the much broader bionic approach. Over a century of intercourse between bionics and aviation technology might serve as a good example to demonstrate this important difference. Starting with the first

*Corresponding author. Email: ralf.neurohr@gmail.com, dragom@cat.mec.pub.ro 
attempts of constructing machines that can fly, researchers and engineers tried to borrow inspirations from nature, thus arriving in some cases at constructions that looked like birds, bats or flying seeds, but were unable to achieve even a minimum percentage of the performance of their natural templates. The final breakthrough in aviation technology is based on the simple recognition that a functioning technical solution can be achieved by the separation of the parts which are generating the lift (wings) and the propulsion (engine). Nevertheless, the airplane industry is still borrowing ideas from nature, like for instance the introduction of the blended winglet, which is based on bionic ideas and research, derived from studies on the aerodynamics of bird winglets during gliding (Figure 1).

\section{The two strategic approaches of bionics}

The former example about the development of the blended winglet is at the same time a typical example for the topdown approach of bionic strategy, which means that starting from a well-defined technical problem, bionics searches for analogous situations in nature that might provide a solution for that specific problem. In these cases, the mission of bionics is the detailed analysis of the system that is providing a potential solution, in order to understand how this proposal of nature can be transformed into a technical system with similar properties but not necessarily a similar shape. The whole process of development and optimisation can be described as a dialog between the world of technol- ogy and the world of biology. As demonstrated in Figure 1, there may be some early results which appear very similar to the original proposal of nature but the shape of the final technical solution (like the blended winglet) in many cases will not be traced back to its natural origin.

The complementary strategy, the bottom-up approach of bionics, does not start with a well defined problem that has to be solved, but with a (sometimes new) discovery in biological research, that is fully described and well understood. The recognized principle is then translated into an abstract, formal and interdisciplinary description of the phenomenon, which opens the pathways for the transfer into different fields of technology. A well-known example of this approach is the so-called 'Lotus-Effect', which has led to many new applications in nano-structured surface design (Figure 3).

\section{Some final remarks}

In order to conclude this short introduction into bionics we may summarise: Bionics is not to be defined by a specific set of subjects or fields of applications, but by a methodological approach that uses two strategies in order to transfer inventions of nature into technical solutions. In this way it is not covering those booming new disciplines like bio- and genetic engineering, nanotechnology, or bioinformatics, but in many cases, the transfer of ideas and knowledge from biology into the world of engineering is the starting point for the development of such new disciplines. Therefore, the
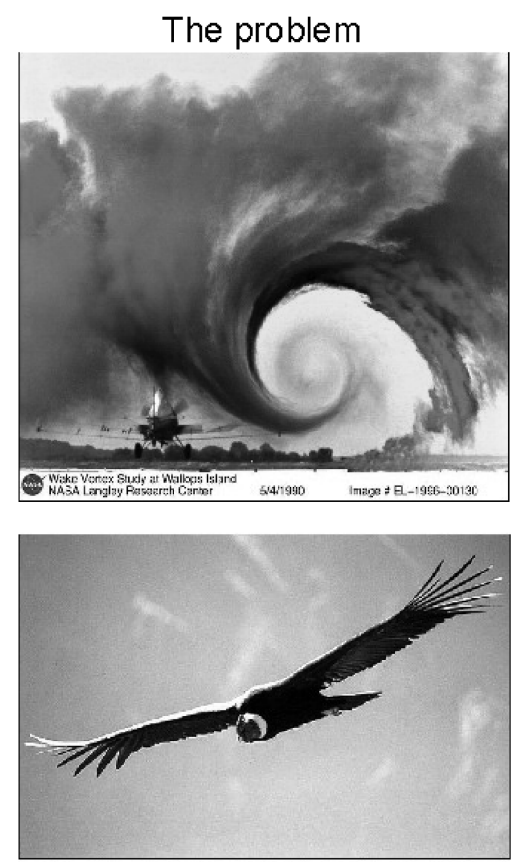

Possible solution from nature?
Bionic optimization
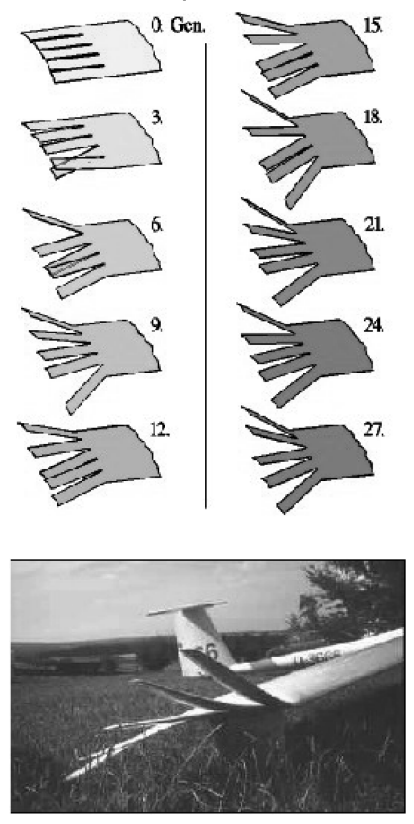

Early prototype

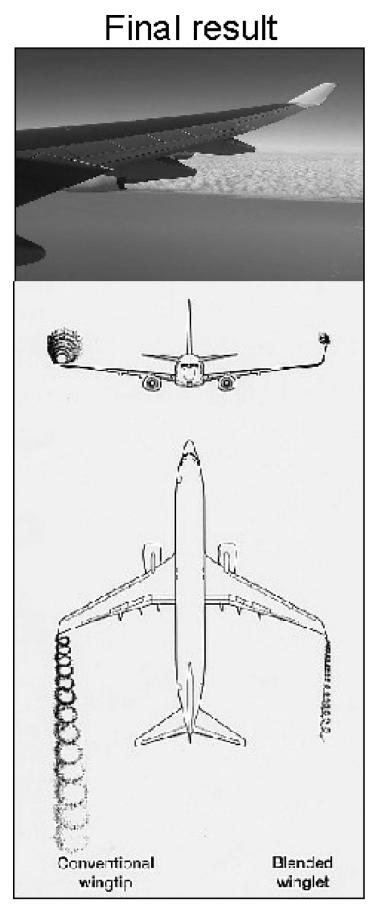

Figure 1. Using bionic methods to minimize the energy loss due to vortex generation at the wing tips of airplanes. 
Top-down approach

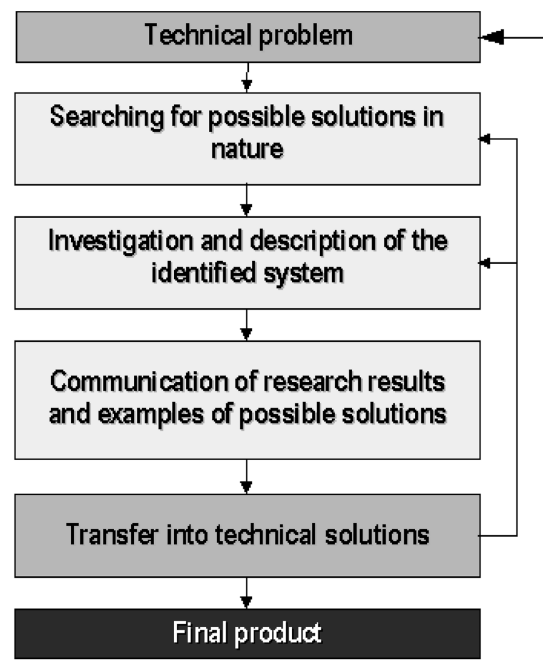

Domain:
Bottom-up approach

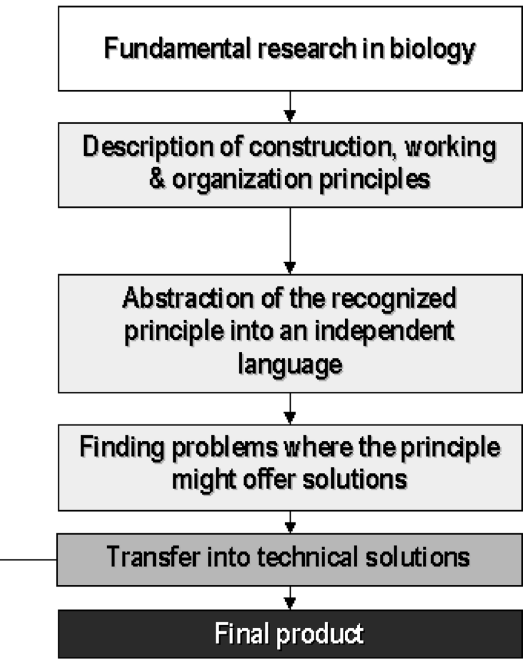

Biology

Figure 2. The two strategic approaches to integrate bionics into technological development

development of a systematic approach, with the provision of an abstract interface between fundamental research in biology and innovative engineering, was very important. The time has come to implement appropriate teaching concepts in engineering education.

It also has to be emphasized that there are growing and solid requests from various industries for bionic ex- pertise in future engineers. It is more and more recognised that future technologies will gain at least a part of their innovative potential out of inspirations and ideas that are coming from nature. As an example of this trend the presentation of the study of a bionic car (Ellenrieder 2005) by Daimler Chrysler in late 2005 (Figure 4) should be mentioned.
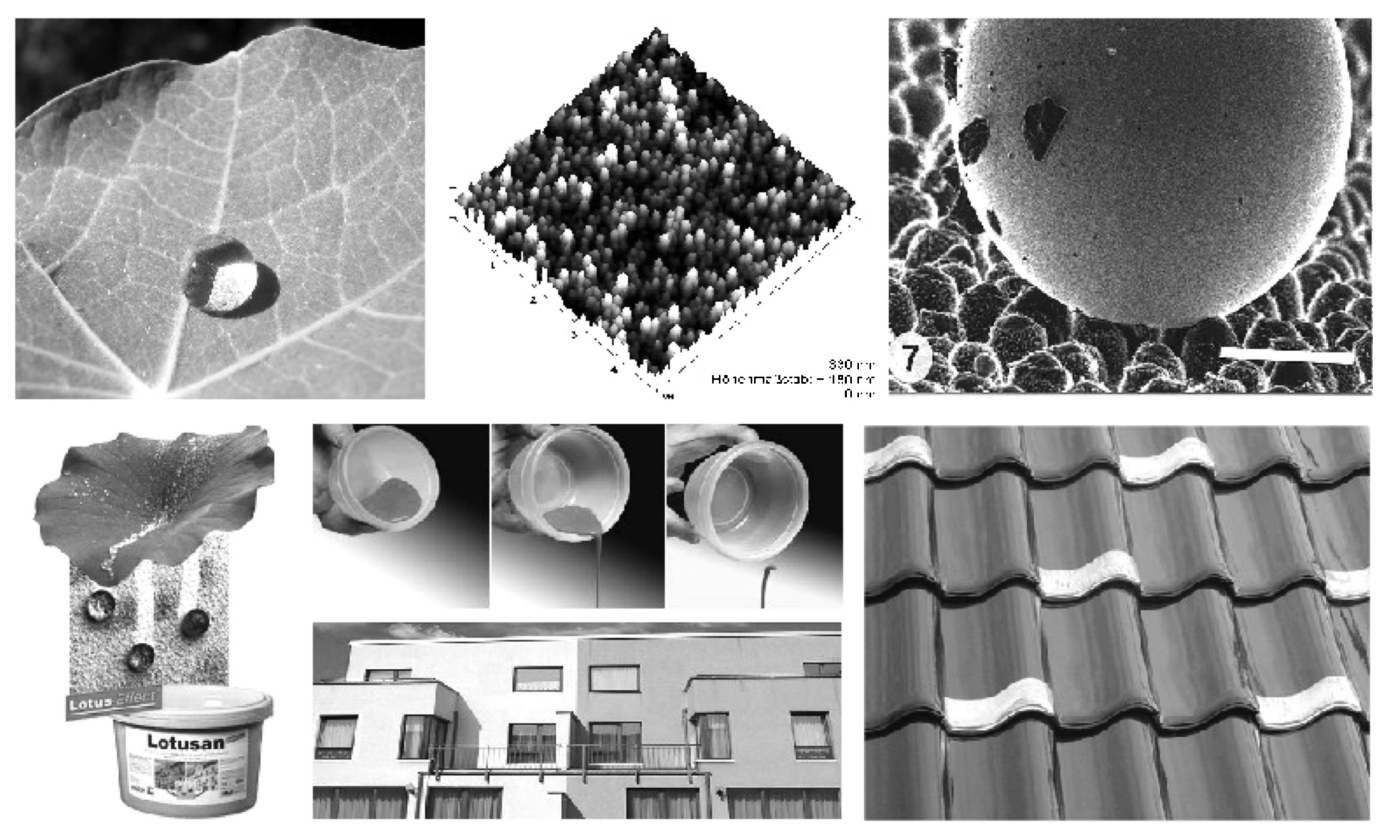

Figure 3. Top: Lotus-Effect at work in nature. Bottom: Products based on the Lotus-Effect (paint, self cleaning food container, self cleaning roof) 


\title{
Mercedes-Benz bionic car
}

\author{
vorgestellt bei der Fachtagung „Bionik im Automobil“ (6. \& 7. Dezember 2005)
}

\section{Aerodynamik und Rohbaustruktur sind Kernthemen des Mercedes-Benz bionic cars:}

\begin{abstract}
„Ein Beispiel, das die Anforderungen der automobilen Welt sehr gut erfüllt, ist der Kofferfisch. Dieser Fisch hat trotz seines kantigen, würfelförmigen Rumpfes hervorragende Strömungseigenschaften und stellt deshalb ein aerodynamisches Ideal dar. Hinzu kommt, dass seine rechteckige Anatomie mit dem Querschnitt einer PkwKarosserie nahezu identisch ist."
\end{abstract}
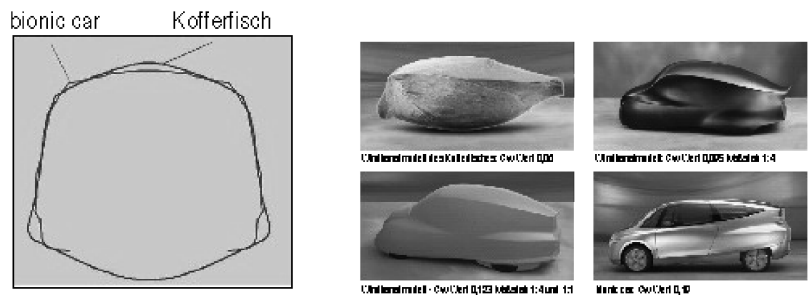
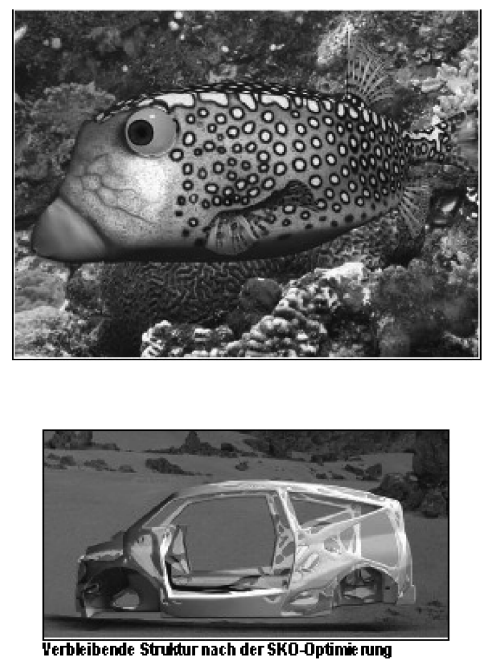

Figure 4. Bionic car presented by Daimler Chrysler in December 2005

\section{How to introduce bionics in engineering education?}

The introduction of bionics in engineering education is not a trivial challenge. Due to the novel character of the discipline, the availability of approved or established concepts is rather limited and the best choice is to rely on the example and experience of the the German BioKoN network, which might be seen as one of the most advanced institutions worldwide for establishing bionic expertise.

Among all members of BioKoN, the University of Applied Sciences in Bremen, Germany is so far the most important entity for our considerations, as the course 'International bachelor's degree in Biomimetics/Bionik' was already established there in 2003/2004. In Europe this is the first institution which awards an official degree in the discipline of bionics. The curriculum of this course (Figure 5) might serve as a master template or example that can be modified for the implementation of educational concepts in engineering science.

\section{Bionics at 'Politehnica' University of Bucharest}

Basic considerations and ideas

The 'Politehnica' University of Bucharest (UPB) is the oldest and one of the leading schools for engineers in Romania. In order to cement this leading position and recognising the importance of bionics in future engineering, the UPB Sen- ate decided in December 2006 to implement a course in bionics, intended to be the starting point for further activities in this field.

As there are, at least officially, no activities in this field in this country. Infrastructures and resources have to be created and, as a first step, the contact to BioKoN was established. Only a few months after the decision of the Senate, with the support of BioKoN it was possible to offer the course 'Introduction into Bionics for Engineers'. The main goals of this course and all other activities related to it were:

- Verification of the students' interest and acceptance.

- Adoption and modification of the initial draft of the course concept according to the students' background knowledge, based on the direct feedback given by them.

- Establishment of contacts to other groups at UPB, in order to find contributors to a future network.

- Establishment of first contacts to different industries, in order to include their feedback in future activities.

\section{Transfer into practice, experiences and results}

Although the course was optional for the students, there were 19 subscriptions, which can be considered an unexpectedly high value. Optional courses at 'Politehnica' are 


\begin{tabular}{|c|c|c|c|c|c|c|}
\hline \multicolumn{7}{|c|}{ Semester } \\
\hline 1 & 2 & 3 & 4 & 5 & 6 & 7 \\
\hline hodul 1.1 & Hodul 2.1 & Modul 3.1 & Hodul 4.1 & Modul 5.1 & Modul 6.1 & Modul 7.1 \\
\hline Chemistry / Physics I & Chemistry / Physics II & $\begin{array}{l}\text { Advanced } \\
\text { Biology }\end{array}$ & Locomotion & $\begin{array}{c}\text { Preparations } \\
\text { for semester } \\
\text { abroad }\end{array}$ & $\begin{array}{l}\text { Project } \\
\text { "Bionik" } \\
\text { Theoryl }\end{array}$ & $\begin{array}{c}\text { Project } \\
\text { „Bionik" II }\end{array}$ \\
\hline Modul 1.2 & Modul 2.2 & Modul 3.2 & Modul 4.2 & Modul 5.2 & Modul 6.2 & Modul 7.2 \\
\hline $\begin{array}{l}\text { Mathematicsi } \\
\text { Informatics I }\end{array}$ & $\begin{array}{l}\text { Mathematicsi } \\
\text { Informatics II }\end{array}$ & Physiology & Materials i Mechanics II & $\begin{array}{l}\text { Semester } \\
\text { abroad }\end{array}$ & $\begin{array}{l}\text { Project } \\
\text { "Bionik" } \\
\text { Praxis I }\end{array}$ & $W_{P} M^{*}$ \\
\hline Modul 1.3 & Modul 2.3 & Modul 3.3 & Modul 4.3 & Modul 5.3 & Modul 6.3 & Modul 7.3 \\
\hline $\begin{array}{c}\text { Biology } \\
\text { and Bionik। }\end{array}$ & $\begin{array}{l}\text { Biology } \\
\text { and Bionik II }\end{array}$ & $\begin{array}{l}\text { Materials I } \\
\text { Mechanics I }\end{array}$ & Finite Element Method I & $\begin{array}{l}\text { Semester } \\
\text { abroad }\end{array}$ & $\begin{array}{l}\text { Advanced } \\
\text { Materials } \\
\text { science I }\end{array}$ & $W_{P} M^{*}$ \\
\hline Modul 1.4 & Modul 2.4 & Modul 3.4 & Modul 4.4 & Modul 5.4 & Modul 6.4 & Modul 7.4 \\
\hline $\begin{array}{l}\text { Preparation-techniques } \\
\text { । }\end{array}$ & $\begin{array}{c}\text { Preparation-techniques } \\
\text { II }\end{array}$ & $\begin{array}{c}\text { Computer } \\
\text { Aided } \\
\text { Design (CAD) I }\end{array}$ & Measurement-techniques & $\begin{array}{l}\text { Semester } \\
\text { abroad }\end{array}$ & Exkursions & $\begin{array}{l}\text { Bachelor } \\
\text { Thesis }\end{array}$ \\
\hline Modul 1.5 & Modul 2.5 & Modul 3.5 & Modul 4.5 & Modul 5.5 & Modul 6.5 & Modul 7.5 \\
\hline $\begin{array}{c}\text { Communicative } \\
\text { Competence I }\end{array}$ & $\begin{array}{l}\text { Communicative } \\
\text { Competence }\end{array}$ & $\begin{array}{l}\text { Communicative } \\
\text { Competence III }\end{array}$ & $\begin{array}{l}\text { Communicative } \\
\text { Competence } \mathrm{V}\end{array}$ & $\begin{array}{l}\text { Review of } \\
\text { semester } \\
\text { abroad }\end{array}$ & WP $W^{*}$ & $\begin{array}{c}\text { Bachelor's } \\
\text { Thesis }\end{array}$ \\
\hline
\end{tabular}

* Miahl Pflicht Modul" MiPM)

in Semesters 6 and 7 at least one of these modules (Module title $6.6-6.8$ or $7.6-7.9$ ) must be attended.

Figure 5. The schedule of Bachelor in bionics at University of Bremen, Germany (from: http://bionik.fbsm.hsbremen.de/pages_english/st_modules.html)

sometimes not very well accepted because the student's schedules do not offer much time for additional lessons. Moreover, the numerus clausus of the German Department at UPB is about 50 students each year. The feedback from the students during the course was positive and spontaneous and it was evaluated in detail at the end of the semester with a questionnaire, which addressed four different aspects of the course and their success in the eyes of the students (Figure 6). The most important results of this evaluation can be found in the next section.

The initial course concept, which was partially based on materials for an introductory course in bionics at the University of Applied Sciences, Saarbrücken, Germany (Braun $\mathrm{K}$, personal communication), needed some modifications because of the inhomogeneous backgrounds of the students who came from higher and lower academic years. As supplementary materials the students received the slides for each lecture, which for the next course will be complemented by a printed booklet.

Concerning the establishment of academic contacts in order to build up a network within the university or the establishment of industrial partnerships, it is yet too early for some final statements. But at least for industry related activities it turned out that there is a lack of information about bionics and so, it would be useful to consider the offering of courses like summer schools or weekend seminars for external participants in the future. According to the experience of some BioKoN members, German managers discovered that they could gain a lot of inspiration from bionic creativity trainings.

\section{Curriculum}

Instead of presenting a more or less detailed and systematic overview on all branches and fields of bionics, the broad range of possible applications was demonstrated by an extended chapter on the history of bionics. This strategy is to provide the space to focus the theoretical part on methodological aspects, like (1) the comparison between the topdown and the bottom-up approach, (2) the importance of a clear distinction between biomimetics and the creative process of abstraction and translation of natural principles and (3) the limits of simple copying. The pragmatic aspects of applied bionics were covered by an extended presentation of the discovery of the winglet effect, including a detailed description of the work that was done in simulation, modelling and optimisation experiments in the wind channel laboratories, thus also giving the students an idea about the meaning of interdisciplinary collaboration. Although not planed in the initial concept, an additional small experimental module was introduced, targeting the demonstration of measuring and experimenting on living systems, which are by far less controllable then technical experiments. Following some students' requests, this chapter was completed by a short excursion into the field of applied statistics in the evaluation experimental data. 


\section{Final Evaluation (Questionnaire)}

- Main Goals

- Basic understanding of bionics

- Self estimate of the learning success

- Estimate of the importance of bionics

\section{- Motivation \& Expectations}

- Motivation for visiting the course

- Degree of satisfaction of expectations
- Qualitative Aspects

- Instructor and presentation style

- Compilation of curriculum

- Materials provided

- Level of the course

- Problem issues / subjects

\section{- Curriculum}

\section{8 questions on specific aspects concerning details of the curriculum and the format of the course.}

Figure 6. Aspects, covered by the course evaluation according to the student's perception

\section{Course evaluation}

Since the whole course can be seen as a kind of teaching experiment, exploring several aspects of the introduction of bionics into engineering education, the students' feedback was evaluated with a questionnaire at the end of the course. Beside the issues of general interest for the introduction of bionics into engineering education, some other questions targetted very specific conditions at 'Politehnica' Bucharest. These latter results will not be presented in this chapter.

Although a minority of students reported the impression that their understanding of bionics could still bear improvement after attending the course, all students claimed that their knowledge in and understanding of bionics significantly increased and none of the students would question the importance of bionics in engineering education in general or the introduction of the subject at their own university. Beside curiosity $(73 \%)$, the motivations for visiting the course were the importance of the issue $(53 \%)$ and the general interest in biological topics (47\%); none of the students regretted her or his decision to invest some extra time for visiting the course.

Among the questions which were targeting qualitative aspects, there are only two results of general interest: as the course was not based on a specific book or manuscript, the slides, created for the lecture, were handed out to the students, in order to provide some written materials for the preparation of the exam. The vast majority of the students' $(87 \%)$ considered these materials as sufficient for reworking the lectures and the preparation of the exam. This means that the current lack of textbooks for a general introductory course in engineering science is not a crucial point for success. A somehow surprising result was the fact that there were also some students who would have liked a more detailed presentation in classical engineering basics like technology, mathematics or physics. Although this might be explained by the mixing of students from different semesters and different streams (economical engineering, mechanics, electrical engineering), this is a clear proof for the necessity of coordinating the curriculum with all faculty involved.

The evaluation of the questions regarding the curriculum uncovered an important but also expected demand of the students for additional experimental modules and exercises. The vote for additional exercises was $100 \%$ and does not require any further comment, except for the fact that not all of the students $(30 \%)$ are willing to accept additional hours for these exercises, which can be explained by the rather tight schedules. A possible solution might be the introduction of weekend seminars or block courses during holidays, which were proposed by some of the students.

\section{Conclusions and perspectives}

Based on the experience during the course itself, the information gathered by all other activities, discussions with representatives from the university and industry and - especially because of the high acceptance and positive feedback from the students - the attempt of introducing bionics into engineering education at 'Politehnica' has to be considered as a successful experiment. However, this conclusion is not limited to UPB, the time is ripe to develop concepts for and introduce bionics into engineering education. Based on our experience, the main guidelines should be:

- Implementation of a general introductory course, addressing all semesters and also different faculties.

- Development of additional courses, offering more specific, detailed and deeper insight. These courses 
should also offer experimental modules and exercises.

- Because of the traditionally very solid background of the students in the fundamentals of engineering, like measurement, mathematics, physics and computing, all teaching activities should be focused more on the biological and experimental aspects of bionics.

- The dialog with industrial partners should be continued and intensified, not only in order to include their requirements as much as possible in the concepts, but also to gather them as contributors to networks like the German BioKoN.

For the special case of 'Politehnica' Bucharest it has to be noticed that there is still no appropriate infrastructure for establishing a permanent competence in the field of bionics and so the highest priority should be the investment into such an infrastructure.

\section{Acknowledgement}

The work presented in this paper would not have been possible without the kind support of Dr. (DVM) Knut Braun, the coordinator of the BioKoN network at Saarbrücken University and the students at 'Politehnica' University of Bucharest, who were accepting and visiting an optional course just because they decided to broaden their horizon, while taking part in a novel teaching experiment. The present paper is partially based on a preliminary presentation of the subject at the International Conference on Engineering Education, September 3-7, 2007 in Coimbra (Portugal). The authors also want to thank the organizers of that conference.

\section{References}

BIOKON - Competence in Bionics [Internet]. Available from: http://www.biokon.net

Ellenrieder G, 2005, Mercedes-Benz bionic car. Fachtagung Bionik im Automobil, 6. \&; 7. Dezember 2005, Ulm, Germany.

Nachtigall W. 2003. Bionik, 2nd ed., Berlin/New York: Springer.

Nachtigall W, Einsatz und Produktpotentiale der Technischen Biologie und Bionik [Internet]. Available from: http://www.unisaarland. de/fak8/bi13wn/wabionik.htm

Neumann D. 1993 Technologieanalyse bionik. Analyse und bewertunge zukünftiger technologien. VDI-Technologiezentrum, Physikalische Technologien, Düsseldorf, Germany.

Neurohr R, C. Dragomirescu, Bionics in Engineering - Defining new Goals in Engineering Education at 'Politehnica'. International Conference On Engineering Education (ICEE-2007); September 3-7, 2007; Coimbra, Portugal.

Neurohr R. The first course in Bionics at 'Politehnica' University of Bucharest Part 1 and 2, internal report, UPB (FILS), June 2007. Available: mailto:ralf.neurohr@gmail.com

University of Applied Sciences, Bremen, Dept. for Biomimetics [Internet]. Available from: http://bionik.fbsm.hs-bremen.de/ indexenglish.htm 

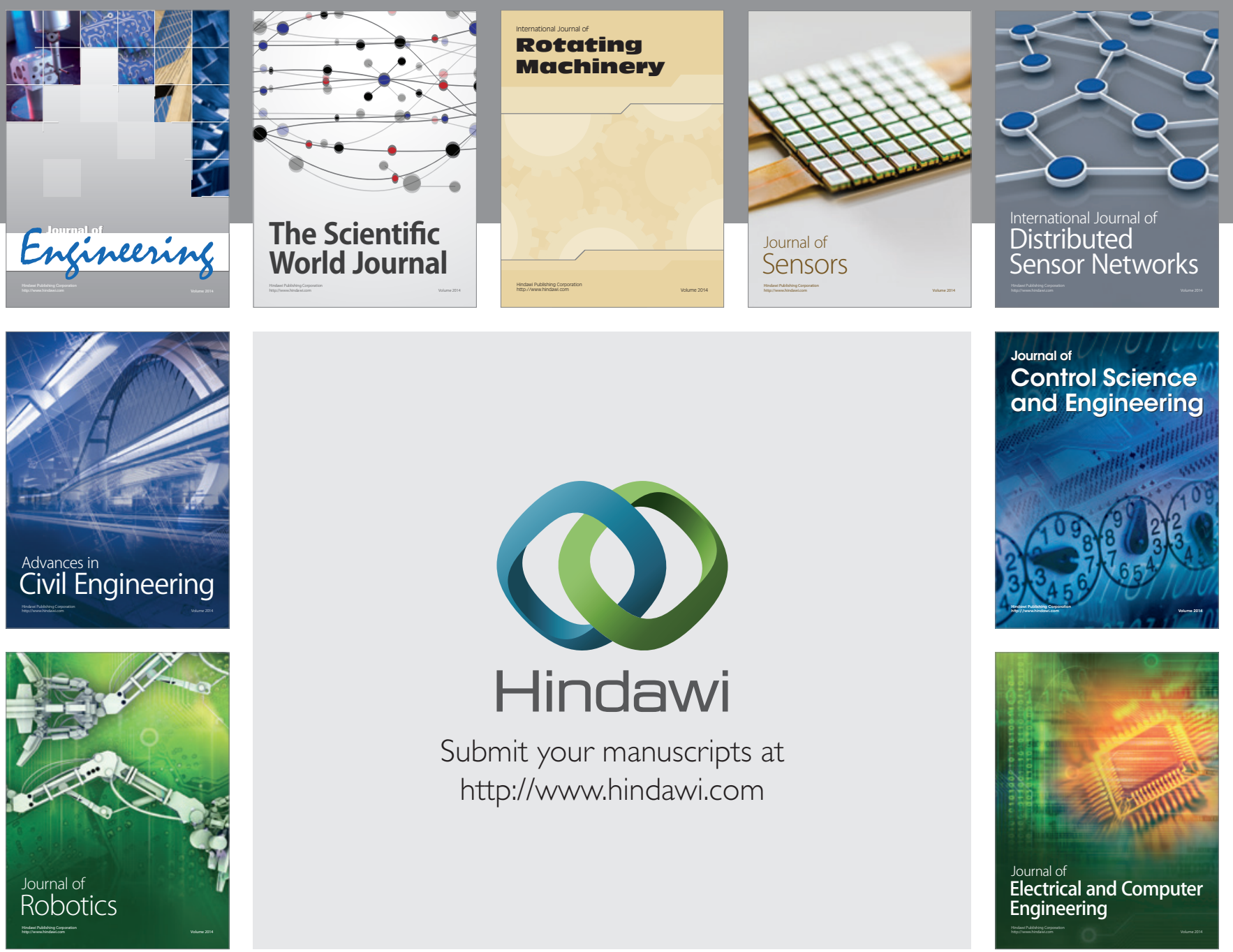

Submit your manuscripts at

http://www.hindawi.com
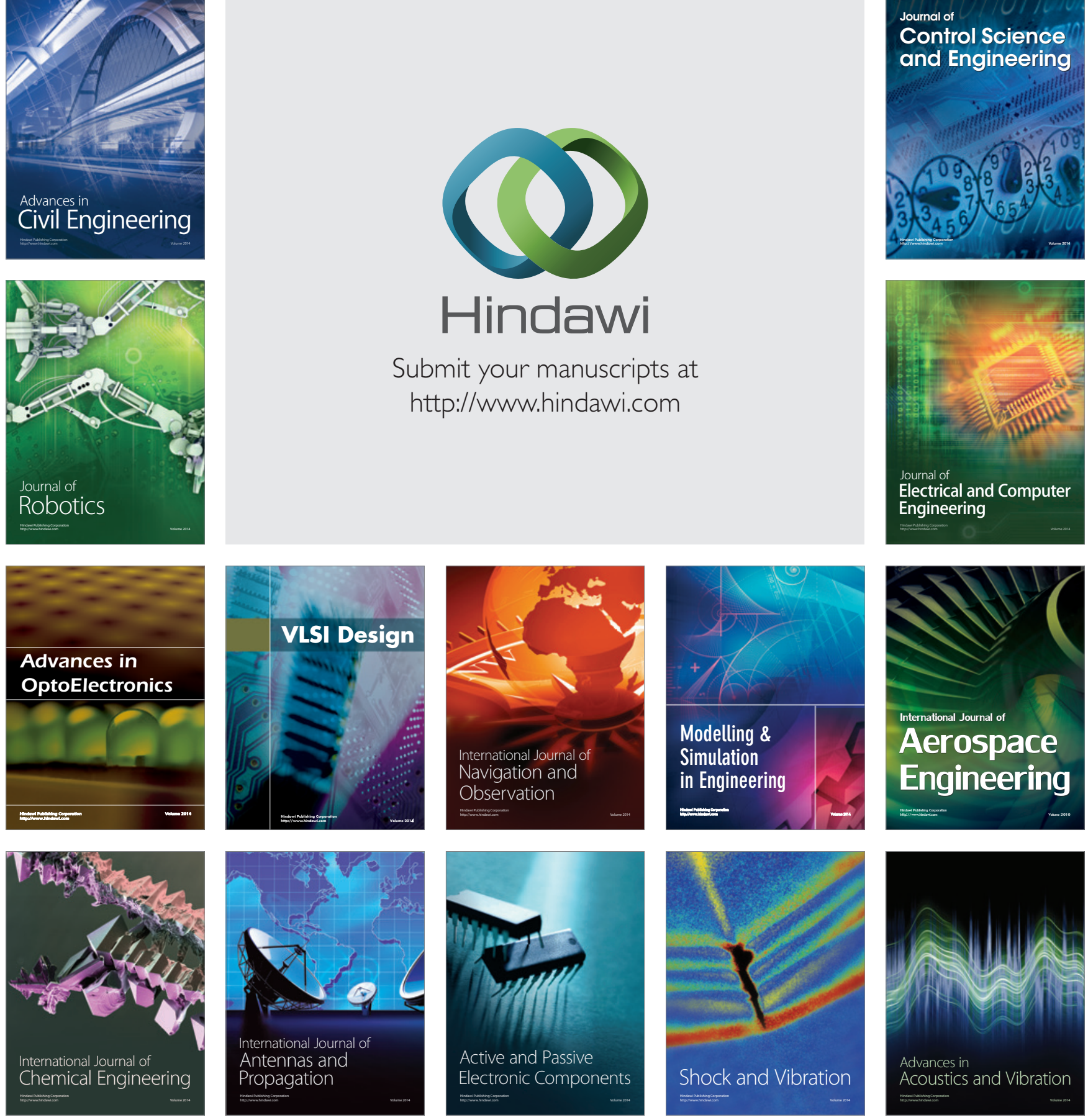